\title{
Examining The Relationships between Attitude Towards Behaviour, Subjective Norms and Entrepreneurial Intention among Engineering Students
}

\author{
Ummi Naiemah Saraih ${ }^{1,}$, Ain Zuraini Zin Aris ${ }^{1}$, Suhana Abdul Mutalib ${ }^{2}$, Tunku Salha Tunku Ahmad ${ }^{1}$, and Mohd Harith \\ Amlus $^{1}$
}

${ }^{1}$ School of Business Innovation and Technopreneurship, Universiti Malaysia Perlis (UniMAP), Malaysia

${ }^{2}$ School of Human Development and Technocommunication, Universiti Malaysia Perlis (UniMAP), Malaysia.

\begin{abstract}
The purpose of this research is to investigate the relationships between attitude towards behaviour, subjective norm and entrepreneurial intention among engineering students from Public Higher Educational Institution (PHEI) in Malaysia. This research is carried out by using the quantitative method (questionnaire). Data are gathered from 345 respondents which consisted of the final year students from one PHEI in Malaysia. Results presented that entrepreneurial intention are positively associated with attitude towards behaviour $(\beta=.62, p<.01)$ and subjective norm $(\beta=.25, p<.01)$. Thus, it is confirmed that both factors of Theory of Planned Behaviour (TPB), namely attitude towards behaviour and subjective norm are significantly related to entrepreneurial intention among the engineering students in this institution. Elevating the degree of attitude towards behaviour and subjective norm are the best strategies to enhance the level of entrepreneurial intention among the engineering students in this institution. Theoretical and practical implications of the results are discussed. In this line, recommendations for the institution management

are

provided
\end{abstract}

\section{Introduction}

Recent research claimed that most of countries faced with the uncertain and complex of unemployment problems. Thus individuals with creative, complex and diversified entrepreneurial knowledge and skills may assist the nation to boost the economies and reduce the unemployment rate [1]. As stated by [2] limited opportunities to grab jobs happened to the competitive environment. In line with this statement, [3] mentioned that graduates from university and college found some difficulties to secure their employment in both public and private sectors due to the current volatile economic environment. Therefore, there is a need to switch and focus on entrepreneurship as a gateway to the employment creation in order to stabilize the economies.

To this point, [4] presented that students from the background of non-economic and business programs are significantly related to students' intentions to become the entrepreneurs. Moreover, the importance of entrepreneurship development could solve the unemployment problems [5]. Therefore, entrepreneurship education is important key point to promote entrepreneurship development to the countries' economy. In the Malaysian context, Ministry of Higher Education Malaysia (MoHE) has taken initiatives to make entrepreneurship as a compulsory subject to all of educational programs under the public universities. Hence, entrepreneurial element has been focused among the most important element to produce students with the entrepreneurial minds (National Education Blueprint, Higher Education).

Self-employment as an entrepreneur is a career that must be given attention as an alternative for graduates besides those employed in facing the volatile limited job market and high retrenchment rate [6]. Hence, an investigation is warranted to reveal the level of entrepreneurial intention among students who are not in the non-economic and business programs (eg. engineering students). This is because entrepreneurship can provides a source of income when an economy cannot yet supply enough jobs [7].

Moreover, MoHE reported that the unemployment percentage for the first degree graduates from the sub field of technical and engineering were $33.7 \%$ in 2015 [8]; and $33.2 \%$ in 2014 [9]. It showed that the percentages of unemployment among graduates in these sub fields seemed high. Thus, it is assumed that the current engineering students in the Malaysian public universities have a low to moderate level of intention to become the future entrepreneurs. Thus, the researchers attempt to investigate the level of entrepreneurial intention among students from the engineering programs in one of public university in Malaysia. Based on the findings of this study, the appropriate initiatives can be well-planned to decrease the unemployment percentage among the future engineering graduates in Malaysia.

\footnotetext{
* Corresponding author: ummi@unimap.edu.my
} 


\section{Literature Review}

\subsection{Theory of Planned Behaviour (TPB)}

Theory of Planned Behaviour, or TPB was a theory that linked between human belief and human behaviour. The concept of TPB is proposed by Icek Ajzen to improve on the predictive power of the Theory of Reasoned Action (TRA). Attitude towards the behaviour, social norm with respect to the behaviour, and perceived control over the behaviour are usually found to predict behavioural intentions with a high degree of accuracy. Behavioural intention is referred toan indication of an individual's readiness to perform a given behaviour. It is assumed to be an immediate antecedent of behaviour [10]. Behavioural intention is identified as the best predictor of behaviour [11]. In this study, behavioural intention is referred to the entrepreneurial intention.

\subsection{Entrepreneurial Intention}

Entrepreneurial intentions is defined by [12] as a commitment to start a new business. This study aimed to find out on students entrepreneurial intention in Saudi University based on several entrepreneurial activities (eg. market challenges, risk taking). In addition, [13] pointed that TPB was an appropriate tool to model the development of entrepreneurial intention through pedagogical processes and learning in among students in Portugal. Meanwhile, [14] defined entrepreneurial intention as a mental orientation such as desire, wish and hope which influence their choice of entrepreneurship. Other authors [15] investigated the impact of education on students' intentions to start-up businesses in Lithuania. In this study, entrepreneurial intention is measured based on a statement of "Yes, I am thinking about own business in the future, when I have completed my studies". With reference to the research results, it is confirmed that beside of the chosen educational program, students in Kaunas University of Technology, Lithuania are inclined to be the entrepreneurs once they completed their studies.

Although TPB factors have been proven as predictors to individuals' entrepreneurial intention, lack evidence is known regarding the influences of attitude towards behaviour and subjective norm on entrepreneurial intention among the engineering students in Malaysia. Therefore, this study aimed to investigate the relationship between two factors of TPB (eg. attitude towards behaviour, subjective norm) and entrepreneurial intention among the engineering students in the Malaysian context.

\subsection{Attitude towards Behaviour, Subjective Norms and Entrepreneurial Intention}

Attitude towards behaviouris the first predictor of entrepreneurial behaviour in this study. In general, the more favourable the attitude towards the behaviour, the stronger individuals intent to perform the behaviour [16]. For example, [18] presented that students with positive attitude towards entrepreneurship education inclined to become entrepreneurs once they completed their studies. Similarly, [15] confirmed that attitude towards entrepreneurship was the main factor of students' entrepreneurial intention in Lithuania. Besides, [19] found that personal attitude affected entrepreneurial intention among the secondary students in Portugal. Also, it is confirmed that entrepreneurial attitude is significantly related to entrepreneurial intention among the university students in Xi'an, China [14].

Subjective norm is the second predictor of entrepreneurial intention in this study. It is defined as the perceived social pressure to perform or not to perform the behaviour [16]. Perceived social pressure to perform or not to perform the entrepreneurial behaviour may be triggered from family, friends, teachers and other possible role models. For example, a study of [14] found that students' subjective norm in China is significantly related to entrepreneurial intention. Similarly, [17] found that subjective norm played major role and created influence on entrepreneurial intention among the business students in Bangalore. Moreover, findings of [18] research presented that entrepreneurship education stimulated students' subjective norm and their intentions towards the entrepreneurship. Based on the existing literature, the specific hypotheses are developed as follows:

$\mathrm{H}_{1}$ : There is a moderate level of entrepreneurial intention among the engineering students in this institution.

$\mathrm{H}_{2}$ : There is a significant relationship between attitude towards behaviour and entrepreneurial intention in this institution.

$\mathrm{H}_{3}$ : There is a significant relationship between subjective norm and entrepreneurial intention in this institution.

\section{Methodology}

This study involved a sample of the engineering students from one of PHEI located in the Northern Region of Malaysia. The adapted instruments used for this study has been presented in Table 1 .

* Corresponding author: ummi@unimap.edu.my 
Table 1. Instrumentation for Variables

\begin{tabular}{|c|c|c|}
\hline Variables & $\begin{array}{c}\text { No of } \\
\text { Items }\end{array}$ & Authors \\
\hline $\begin{array}{c}\text { Entrepreneurial } \\
\text { Intention }\end{array}$ & 9 & {$[20]$} \\
\hline $\begin{array}{c}\text { Attitude } \\
\text { towards } \\
\text { Behaviour }\end{array}$ & 5 & {$[21] ;[22] ;[13] ;[23]$} \\
\hline $\begin{array}{c}\text { Subjective } \\
\text { Norm }\end{array}$ & 8 & {$[24] ;[25] ;[26]$} \\
\hline
\end{tabular}

Out of 500 distributed questionnaires, 345 returned questionnaires have been used for further analysis.

\section{Findings Analysis}

\subsection{Profile of the Respondents}

Results from the descriptive analyses showed that $60.6 \%$ (209) in this survey were females and the remaining 39.4\% (136) were males. Most of the respondents $(83.5 \%)$ were in the age between 21 to 23 years old. This figure is followed by respondents from age of 24 to 26 years old $(15.9 \%)$, age of 27 to 29 years old $(.3 \%)$ and above than 30 years old $(.3 \%)$. The majority of respondents were Malays which contributed of $64.6 \%$ (223 participants). The race categories are followed by 91 Chinese $(26.4 \%), 21$ others $(6.1 \%)$ and 10 Indians $(2.9 \%)$.

With regards the schools categories, the respondents came from the various types of schools/faculties. The majority of respondents came from School of Engineering Technology which contributed about $42.0 \%$. This figure is followed by respondents from School of Computer and Communication Engineering (35.4\%), School of Manufacturing Engineering (21.2\%) and School of Mechatronics Engineering (1.2\%). The small percentage of the respondents which contributed of $.3 \%$ came from School of Microelectronics Engineering. Meanwhile, more than half of the respondents $(65.8 \%)$ came from families which have the business background.

\subsection{Reliability Analysis}

As presented in Table 2, the Cronbach's Alpha values are reported at .68 for entrepreneurial intention, .79 for attitude towards behaviour and .80 for subjective norm.

Therefore, the reliabilities of variables used in this research are indicated as acceptable and good [27].
Table 2. Reliability Analysis

\begin{tabular}{|c|c|c|c|}
\hline Variables & N & $\begin{array}{c}\text { Cronbach } \\
\text { Alpha }\end{array}$ & Remarks \\
\hline $\begin{array}{c}\text { Entrepreneurial } \\
\text { Intention }\end{array}$ & 345 & .68 & Acceptable \\
\hline $\begin{array}{c}\text { Attitude towards } \\
\text { Behaviour }\end{array}$ & 345 & .79 & Good \\
\hline Subjective Norm & 345 & .80 & Good \\
\hline
\end{tabular}

\subsection{Mean and SD Analyses}

As presented in Table 3, the means for all variables were relatively high, with the means for all variables exceeding the scale mid-point of three. In this study, the interpretation of mean scores have been interpreted in the ranged of low (1.00-1.66), moderate (1.67-3.33) and high (3.34-5.00). Based on the result, it is noted that the mean for entrepreneurial intention is also high at 3.67. Therefore, $\mathrm{H}_{1}$ is not supported in this study. In the perspective of predictors, the means ranged from 3.43 for subjective norm to 3.64 for attitude towards behaviour. Hence, it can be confirmed that not only for entrepreneurial intention, respondents in this study also have high levels of attitude towards behaviour as well as their subjective norm.

Table 3. Mean and SD Values

\begin{tabular}{|c|c|c|c|}
\hline Variables & $\mathbf{N}$ & Mean & SD \\
\hline $\begin{array}{c}\text { Entrepreneurial } \\
\text { Intention }\end{array}$ & 345 & 3.67 & .54 \\
\hline $\begin{array}{c}\text { Attitude } \\
\text { towards } \\
\text { Behaviour }\end{array}$ & 345 & 3.64 & .62 \\
\hline $\begin{array}{c}\text { Subjective } \\
\text { Norm }\end{array}$ & 345 & 3.43 & .63 \\
\hline
\end{tabular}

The SD values for entrepreneurial intention, attitude towards behaviour and subjective norm are reported at .54, .62 and .63 respectively. These low levels of all SD values showed that most respondents were close to the mean for all variables in this study.

\subsection{Correlation Analysis}

As shown in Table 4, entrepreneurial intention are positively and significantly correlated with attitudes towards $(\mathrm{r}=.75, \mathrm{p}<.01)$ and subjective norm $(\mathrm{r}=.59, \mathrm{p}<.01)$.

Table 4. Correlation Analysis

\begin{tabular}{|c|c|c|c|c|}
\hline Variables & $\mathbf{N}$ & $\mathbf{1}$ & $\mathbf{2}$ & $\mathbf{3}$ \\
\hline $\begin{array}{c}\text { 1. Entrepreneurial } \\
\text { Intention }\end{array}$ & 345 & - & & \\
\hline $\begin{array}{c}\text { 2. Attitude towards } \\
\text { Behaviour }\end{array}$ & 345 & $.75^{* *}$ & - & \\
\hline 3. Subjective Norm & 345 & $.59^{* *}$ & $.56^{* *}$ & - \\
\hline
\end{tabular}

$* *$ Correlation is significant at the 01 level (2-tailed) 
Also, analysis presented a significant positive correlation between attitude towards behaviour and subjective norm $(\mathrm{r}=.56, \mathrm{p}<.01)$. Therefore, the correlations for all variables are reported as significantly and positively between each other.

\subsection{Regression Analysis}

As shown in Table 5, 61.0\% of the variance in entrepreneurial intention is explained by attitude towards behaviour and subjective norm $\left(\mathrm{R}^{2}=.61\right)$.

Table 5. Regression Analysis

\begin{tabular}{|c|c|c|}
\hline \multirow{2}{*}{ Variables } & \multicolumn{2}{|c|}{$\begin{array}{c}\text { Entrepreneurial } \\
\text { Intention }\end{array}$} \\
\cline { 2 - 3 } Beta & Sig. \\
\hline $\begin{array}{c}\text { Attitude towards } \\
\text { Behaviour }\end{array}$ & $.62 * *$ & .00 \\
\hline Subjective Norm & $.25 * *$ & .00 \\
\hline \multicolumn{2}{|c|}{$\begin{array}{c}\mathrm{R}^{2}=0.61 \\
\text { Adjusted } \mathrm{R}^{2}=0.61 \\
\mathrm{~F}=266.853\end{array}$} \\
\hline \multirow{2}{*}{ Correlation is significant at the .01 level (2-tailed) }
\end{tabular}

To further clarify, the remaining of $39.0 \%$ of variance in entrepreneurial intention among these engineering students is explained by the other variables. In addition, the adjusted $\mathrm{R}^{2}$ value also taken into account as .61. Based on the results, entrepreneurial intention is positively associated with attitude towards behaviour $(\beta=.62, \mathrm{p}<.01)$.

Thus, this implied that attitude towards behaviour is significantly related with entrepreneurial intention among the engineering students in this study. Also, it is noted that entrepreneurial intention is positively associated with subjective norm $(\beta=.25, p<.01)$. Thus, this implied that subjective norm is significantly related with entrepreneurial intention among the engineering students in this study. Therefore, $\mathrm{H}_{2}$ and $\mathrm{H}_{3}$ are supported respectively.

\section{Conclusion}

This study presented that the level of entrepreneurial intention among the engineering students in one of the Malaysian PHEI is high with the mean value is reported at 3.67. Therefore, $H_{l}$ : There is a moderate level of entrepreneurial intention among the engineering students in this institution is not supported in this study. In addition, this study provide some new knowledge pertaining the relationships between attitude towards behaviour, subjective norm and entrepreneurial intention among engineering students in this institution.
As indicated in Table 5, entrepreneurial intention are positively associated with attitude towards behaviour $(\beta=.62, \mathrm{p}<.01)$ and subjective norm $(\beta=.25, \quad \mathrm{p}<.01)$. Therefore, $H_{2}$ : There is a significant relationship between attitude towards behaviour and entrepreneurial intention in this institution; and $H_{3}$. There is a significant relationship between subjective norm and entrepreneurial intention in this institution are supported in this study.

Based on the results, it can be concluded that by increasing the level of attitude towards behaviour and subjective norm among the engineering students in this institution, the level of entrepreneurial intention among them can be enhanced. In the theoretical perspective, it can be seen that the influences of both factors of TPB namely attitude towards behaviour and subjective norm are significantly related to entrepreneurial intention among the engineering students in Malaysia. These findings were consistent with the previous findings as reported by several authors. For example, [13] presented that attitude towards behaviouris significantly related with entrepreneurial intention among the secondary students in Portugal. Similarly, [15] found that attitude towards entrepreneurship is one of the main factors of entrepreneurial intention among students to start-up business in Lithuania. This result implies that the more positive attitudes the student have towards entrepreneur behaviour, the more intention they will have on entrepreneurship.

In the perspective of the relationship between subjective norm and entrepreneurial intention, the finding is consistent with a study of [17]. These authors found that subjective norm played major role to influence theentrepreneurial intention among students in Bangalore. Similarly, [18] presented that entrepreneurship education stimulated students' subjective norm and intentions towards entrepreneurship in Botswana. This result implies that the higher level of subjective norm which students have in themselves, the higher level of intention they will have on entrepreneurship. One possible explanation for this result might be because students are influenced by real life examples which provided by their peers (eg. families, friends, etc.).

Practically, detail suggestions to increase the appearance of attitude towards behaviour and subjective norm on entrepreneurial intention may be channelled to the top management in this institution as well as to the students' families and friends. In order to increase attitude towards behaviour among students in the institution, these following actions can be taken by the top management: 1) To convince students that having 
their own business is the other option for their career; 2) To convince students that career as entrepreneur is also attractive; 3) To convince students to start a firm if they have the opportunity; 4) To convince students that being an entrepreneur would entail great satisfactions; and 5) To convince students that if they start their businesses, they will certainly be successful.

Meanwhile, to increase the level of subjective norm among students in the institution, some actions which can be taken by families, friends, and the close or important persons around the students: 1) To convince students that their families, friends and people who are close and important to them wants them to pursue a career as an entrepreneur; 2) To convince students that their parents are positively oriented towards their future career as an entrepreneur; 3) To convince students that their friends see entrepreneurship as a logical choice for them; 4) To convince students that in the universities' environment, students are actively encouraged to pursue their own business; and 5) To convince students that there is a well-functioning infrastructure in the universities to support the start-up of new firms.

\section{References}

1. Iqbal, A., Melhem, Y. \& Kokash, H. Readiness of the University Students towards Entrepreneurship in Saudi Private University: An exploratory Study. European Scientific Journal, 8 (15), 109-131 (2012)

2. Keat, O.Y., Selvarajah, C. \& Meyer, D. Inclination towards entrepreneurship among university students: An empirical study of Malaysian university students. International Journal of Business and Social Science, 2(4), 206-220 (2011)

3. Teshome, T. Attitudes of private higher education students towards entrepreneurship: A case of distance learners in Wolaita Sodo and Hossana Towns. Middle-East Journal of Scientific Research, 19(2), 277-285 (2014)

5. Dilanchiev, A. Relationship between Entrepreneurship and Unemployment: The Case of Georgia. Journal of Social Sciences, 3(2), 5-9, (2014)

6. Mazdan, A. A. Involvement of graduates in the field of entrepreneurship in Kuala Lumpur, Malaysia. International Journal of Liberal Arts and Social Science, 3(9), 46-53 (2015)

7. Kelly, D.J., Bosma, N. \& Amoros, J.E. Global Entrepreneurship Monitor (GEM) (2010)

8. Ministry of Higher Education (MoHE). "Laporan Kajian Pengesanan Graduan 2015" Retrieved from: http://graduan.mohe.gov.my/skpgreport/Penerbitan/SKPG\%202015/6)\%20Bab
$\% 203 \% 20-$

\%20Status $\% 20$ Pekerjaan $\% 20$ Graduan $\% 20201$ 5.pdf (2015)

9. Ministry of Higher Education (MoHE). "Laporan Kajian Pengesanan Graduan 2014" Retrieved from: http://graduan.mohe.gov.my/skpgreport/Penerbitan/SKPG\%202014/6)\%20Bab $\% 203 \% 20-$

\%20Status \%20Pekerjaan $\% 20$ Graduan $\% 20201$ 4.pdf (2014)

10. Ajzen, I. Perceived Behavioral Control, SelfEfficacy, Locus of Control, and the Theory of Planned Behavior. Journal of Applied Social Psychology, 32, 665-683 (2002)

11. Fishbein, M. \& Ajzen, I. Belief, attitude, intention and behavior: An introduction to theory and research. Reading, MA: Addison Wesley (1975)

12. Krueger, N.F. The Impact of Prior Entrepreneurial Exposure on Perceptions and New Venture Feasibility and Desirability. Entrepreneurship Theory and Practice, 18, 521 (1993)

13. do Paco, A.M.F., Ferreira, J.M., Raposo, M., Rodrigues, G.G. \& Dinis, A. Behaviours and entrepreneurial intention: Empirical findings about secondary students. Journal of International Entrepreneurship, 9(1), 20-38 (2011)

14. Peng, Z., Lu, G. \& Kang, H. Entrepreneurial Intentions and Its Influencing Factors: A Survey of the University Students in Xi'an China. Creative Education, 3, 95-100 (2012)

15. Remeikiene, R., Startiene, G. \& Dumciuviene, D. Explaining Entrepreneurial Intention of University Students: The Role of Entrepreneurial Education. Croatia International Conference 2013, 299-307. (2013)

16. Ajzen, I. Theory of planned behavior. Organizational Behavior and Human Decision Processes. 50, 179-211 (1991)

17. Krithika, J. \& Venkatachalam, B. A Study on Impact of Subjective Norms on Entrepreneurial Intention among the Business Students in Bangalore. IOSR Journal of Business and Management, 16(5), 48-50 (2014)

18. Rudhumbu, N., Svotwa, D., Munyanyiwa, T \& Mutsau, M. Attitudes of Students towards Entrepreneurship Education at Two Selected Higher Education Institutions in Botswana: A Critical Analysis and Reflection. Academic Journal of Interdisciplinary Studies, 5(2), 8394 (2016)

19. Ferreira, J.J., Raposo, M.L., Rodrigues, R.G., Dinis, A. \& Paço, A.D. A model of entrepreneurial intention: An application of the psychological and behavioral approaches. 
Journal of Small Business and Enterprise Development, 19(3), 424-440 (2012)

20. Indari \& Kristiansen. Empirical Studies of Self-Employment. Journal of Economic Survey, 13, 381-415 (2003)

21. Nishantha, B. Influence of Personality Traits and Socio-demographic Background of Undergraduate Students on Motivation for Entrepreneurial Career: The Case of Sri Lanka. Euro Asia Management Studies Association (EAMSA). Conference held on 5th December 2008 at Doshisha Business School, Kyoto, Japan. (2009)

22. Sagiri, S. \& Appolloni, A. Identifying the Effect of Psychological Variables on Entrepreneurial Intentions. DSM Business Review, 1(2), 61-86 (2009)

23. Liñán, F. \& Chen, Y.W. Development and Cross-Cultural Application of a Specific Instrument to Measure Entrepreneurial Intentions. Entrepreneurship Theory and Practice, 33(3), 593-617 (2009)

24. Leroy, H., Maes, J., Sels, L. \& Debrulle, J. Gender effects on entrepreneurial intentions: A Tab Multi Group Analysis at factor and indicator level. Paper presented at the Academy of Management Annual Meeting, Chicago (USA) (2009)

25. Leong, C.K. Entrepreneurial Intention: $A n$ Empirical Study among Open University Malaysia Students. Master Thesis, Open University Malaysia (2008)

26. Gurbuz, G. \& Aykol, S. Entrepreneurial intentions of young educated public in Turkey. Journal of Global Strategic Management, 4(1), 47-56 (2008)

27. George, D. \& Mallery, P. SPSS for Windows step by step: A simple guide and reference 11.0 update $\left(4^{\text {th }}\right.$ ed.). Boston: Allyn \& Bacon (2003) 